\title{
Genetic polymorphism of maize somaclonal lines derived from P346 line
}

\author{
D. M. Maidanyuk, I. O. Andreev, K. V. Spiridonova, V. A. Kunakh
}

The Institute of Molecular Biology and Genetics

150 Zabolotny Str., Kyiv 03143, Ukraine

kunakh@imbg.org.ua

\begin{abstract}
Some distinctions between the inbred P346 line and five somaclonal Zea maize lines (UKCh-5, UKCh-6, UKCh-7, UKCh-8, and UKCh-9) obtained from it via tissue culture in vitro have been found through RAPD analysis. The somaclonal lines were shown to differ from each other by the magnitude of genetic distances from the original P346 line as well as by the level of intraline heterogeneity. Positive interrelationship was revealed between these indices. The subset of polymorphic amplicons which distinguish the somaclonal lines from the original one proved to be common for some of them. The results obtained, along with the earlier studies on the individual phenotypic selection and genetic traits, demonstrated that the employment of the tissue culture in vitro together with the appropriate selection methods allow attaining desirable genetic changes.
\end{abstract}

Keywords: maize, tissue culture in vitro, somaclonal lines, RAPD analysis, genome rearrangements

Introduction. Maize is important agricultural crop, global acreage planted and croppage of which top the lists in worldwide production $\left(1^{\text {st }}\right.$ and $2^{\text {nd }}$ places respectively). Both maize grain and vegetative mass are used in agricultural and food industries. Maize is known to be the source of up to 500 products, main and derivative [1]. In Ukraine maize is traditionally important food crop. Moreover, it supplies necessary amounts of green fodder for livestock farming. Maize as an intertilled crop favours eliminating weeds from the fields, and due to this fact maize is widely used in crop rotation as the predecessor of winter and spring cereals.

In the recent years Ukrainian breeders aimed their efforts at rearing the hybrids of early-, mid-, and

(C)

D. M. MAIDANYUK, I. O. ANDREEV, K. V. SPIRIDONOVA,

V.A.KUNAKH, 2007 late-ripening groups of maize [2]. One of the factors, hindering the improvement of varieties and hybrids of maize, is the limitation of genetic variety of samples, applicable for selection. The use of tissue culture in vitro, due to its inherent somaclonal variability, is the promising way to overcoming this obstacle [3]. Somaclonal variability is known to rise in long-term cultured tissues [4]. At the same time regeneration capacity of long-term tissue cultures dramatically declines, thus limiting the possibility of this approach to expand the diversity of available genetic material. Generation of maize lines showing enhanced regeneration potential may improve the application of somaclonal variation in plant breeding.

Previously, at Institute of Plant Physiology and Genetics of NAS of Ukraine via artificial selection including the control over the phases of induction of callus-formation and plant regeneration somaclonal vari- 
ants of inbred Zea maize line P346 were generated from callus cultures showing spontaneous variation $[5,6]$. Based on these variants, UKCh-5, UKCh-6, UKCh-7, UKCh-8, and UKCh-9 Zea maize lines were obtained, which in addition to improved series of agronomically valued traits were distinguished by the increased regeneration potential as compared to original P346 line [5]. The results of analysis, performed at V. Ya. Yurjev Institute of Plant Production of Ukrainian Academy of Agrarian Sciences (UAAS), revealed the presence of genetic differences in various agronomic indices between developed somaclonal lines and P346 line (Gurjeva, unpublished data).

Current work presents the genomic analysis of P346 line and its somaclonal variants using the methods of RAPD-PCR with the purpose of studying molecular and genetic changes, induced by cultivation of maize tissues in vitro.

Materials and Methods. The seeds of inbred Zea maize P346 (Pioneer 346) lines - UKCh-5, UKCh-6, UKCh-7, UKCh-8, and UKCh-9 - were kindly granted by the National Centre for Plant Genetic Resources of Ukraine (NCPGRU), V. Ya. Yurjev Institute of Plant Production (Kharkiv, Ukraine), NCPGRU Registration No. UB0102873, UB0103498, UB0103499, UB0103500, UB0103501, UB0103359, respectively.

Maize seeds were sterilized in $70 \%$ ethanol solution ( $2 \mathrm{~min}$ ) and then in $20 \%$ Domestos aqueous solution (20 min). Then the seeds were washed 6 times with sterile distilled water and put for germination on agarose medium with half amount of salts according to Murashige-Skoog [7]. DNA was isolated from 14-day-old seedlings using cetavlon (CTAB) according to the method described in [8].

Concentration and quality of the obtained preparations were assessed visually by the intensity of fluorescence of DNA-ethidium bromide complexes in UV light after electrophoresis in $1.5 \%$ agarose gel in relation to the control with known concentration (phage $\lambda$ DNA).

PCR reaction mixture, $20 \mu \mathrm{l}$, contained the following ingredients: 1xPCR-buffer with $2 \mathrm{mM} \quad \mathrm{MgCl}_{2}$ (Medbioservice, Ukraine), dNTP $0.2 \mathrm{mM}$ of each, 1 unit of Taq-polymerase (AmpliSense, Russia), $0.25 \mu \mathrm{M}$ of primer (Litech, Russia), 20 ng of DNA. The reaction mixture was layered with $20 \mu \mathrm{l}$ of mineral oil. The following PCR program was used for DNA amplification: denaturation $-94^{\circ} \mathrm{C}, 2 \mathrm{~min} ; 5$ cycles of: denaturation $-94^{\circ} \mathrm{C}, 30 \mathrm{sec}$; renaturation $38^{\circ} \mathrm{C}, 30 \mathrm{sec}$; elongation $-72^{\circ} \mathrm{C}, 1 \mathrm{~min} ; 35$ cycles of: denaturation $94^{\circ} \mathrm{C}, 20 \mathrm{sec}$; renaturation $-38^{\circ} \mathrm{C}, 20 \mathrm{sec}$; elongation $-72^{\circ} \mathrm{C}, 40 \mathrm{sec}$; elongation $-72^{\circ} \mathrm{C}, 2.5$ min. The reaction with each primer was repeated two times. The reaction products were fractionated in $2 \%$ agarose gel with ethidium bromide in 1xTBE-buffer. Band size was estimated by comparison to a DNA size marker $100 \mathrm{bp}+1.5 \mathrm{~Kb}$ (SibEnzyme, Russia).

For statistical analysis the RAPD-profiles of the investigated objects were presented as a binary matrix, where the presence of a band was recorded as 1 and the absence as zero (only clear and reproducible fragments were taken into account). On the basis of the matrix, genetic distances according to Nei [9] were calculated using POPGENE 1.31 software [10].

Results and Discussion. We studied interline distinctions and intraline polymorphism at the level of individual plants in Zea maize line P346 and its somaclonal lines, obtained on the basis of plants regenerated from tissue culture in vitro. Thus, we analysed DNA samples of 9 P346 plants, 10 plants of UKCh-5, UKCh-6, UKCh-8, UKCh-9, and 8 plants of UKCh-7. Molecular and genetic analysis was carried out using PCR with arbitrary primers, namely RAPD-PCR. One of the advantages of this method is the possibility to evaluate a lot of regions, randomly distributed across genome. Analysed primers were selected from those successfully applied in previous studies on genetic polymorphism of maize $[11,12]$. Totally we used 10 decanucleotide primers, data on which are presented in Table 1. Nine primers showed polymorphism between the analysed objects.

PCR run with abovementioned primers invariably produced clear amplification products, the number of which varied from 3 to 13 (Table 1). Total number of amplicons for all objects was 89, of which 68 were revealed in the initial P346 line and 21 were specific to somaclonal variants. The number of polymorphic amplicons was 42 , i.e. $47.2 \%$ of total number of calculated amplification products. Typical polymorphism pattern of PCR-fragments 
of the investigated maize line is presented on electrophoregrams (Fig.1).

Analysis of RAPD-spectra of individual plants allowed singling out two groups of polymorphic frag-

Table 1

Characteristics of primers used for RAPD analysis of inbred maie lines and their products

\begin{tabular}{l|c|c|c|c|c}
\hline \multirow{2}{*}{ Primer } & $\begin{array}{c}\text { Nucleotide sequence } \\
\left(5^{\prime}-3^{\prime}\right)\end{array}$ & \multicolumn{2}{|c|}{$\begin{array}{c}\text { Primers, revealing } \\
\text { polymorphism }\end{array}$} & \multicolumn{2}{|c}{ Number of amplicons } \\
\cline { 3 - 7 } & & Interline & Intraline & P346 & $\begin{array}{c}\text { Somaclon } \\
\text { al lines }\end{array}$ \\
\hline A-01 & CAGGCCCTTC & + & + & 6 & 8 \\
A-12 & ATCGCACACT & + & + & 7 & 7 \\
Ag-01 & AGGTCACTGA & + & - & 8 & 9 \\
B-01 & GTTTCGCTCC & + & + & 3 & 12 \\
AH-30 & TGGTCACTGT & - & + & 5 & 10 \\
M-06 & CTGGGCAACT & + & + & 6 & 6 \\
M-07 & CCGTGACTCA & + & + & 13 & 15 \\
OPA-02 & TGCCGAGCTG & + & - & 9 & 10 \\
OPA-04 & AGTCAGCCAC & + & - & 8 & 9 \\
Total & & 8 & 6 & 68 & 89 \\
\hline
\end{tabular}

Note: the number of amplicons for somaclonal lines indicates the number, detected in the plants of all lines. ments. One of them included the amplicons specific for intraline polymorphism. The example of such polymorphism for plants of UKCh-6 line is given in Fig.2. Generalisation of the results of intraline polymorphism (Table 2) revealed that the analysed somaclonal lines differ in the level of genetic heterogeneity, in particular in the number of plants with polymorphic spectra and the number of variable fragments. UKCh-6 and UKCh-8 lines reveal the highest heterogeneity, while UKCh-5 was the least heterogeneous. At the same time plants of the inbred P346 line exhibited similar spectra.

Polymorphic amplicons, belonging to the second group, showed interline distinctions, but were found to be stable within individual somaclonal lines (Table 3 ). As it is seen from Table 3, the lines involved differ from each other in the number of fragments of this group and, hence, in Nei's genetic distances from the original line P346. The highest number of polymorphic amplicons and the maximal genetic distance from P346 were revealed in UKCh-6 and UKCh-8, while UKCh-5 showed the least values. UKCh- 7 and UKCh-9 had hardly any differences from P346 in the genetic distances and occupied the mid position. It is noteworthy that some amplicons of this group, which
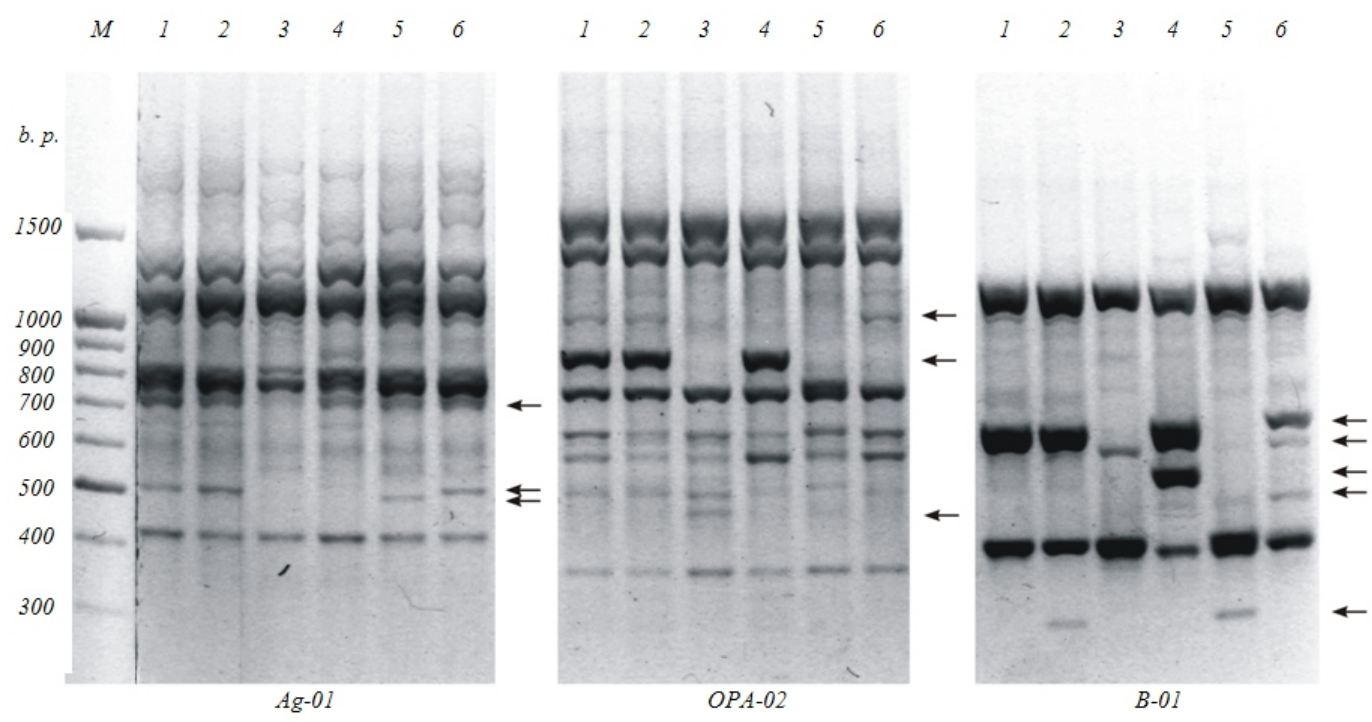

Fig.1 RAPD spectra of investigated maize line DNA samples, obtained with three primers. Polymorphic fragments are marked by arrows. $M$-DNA size marker; 1 - P346; 2 - UKCh-5; 3 - UKCh-6; 4-UKCh-7; 5 - UKCh-8; 6-UKCh-9. The names of primers are written at the bottom of each electrophoregram 


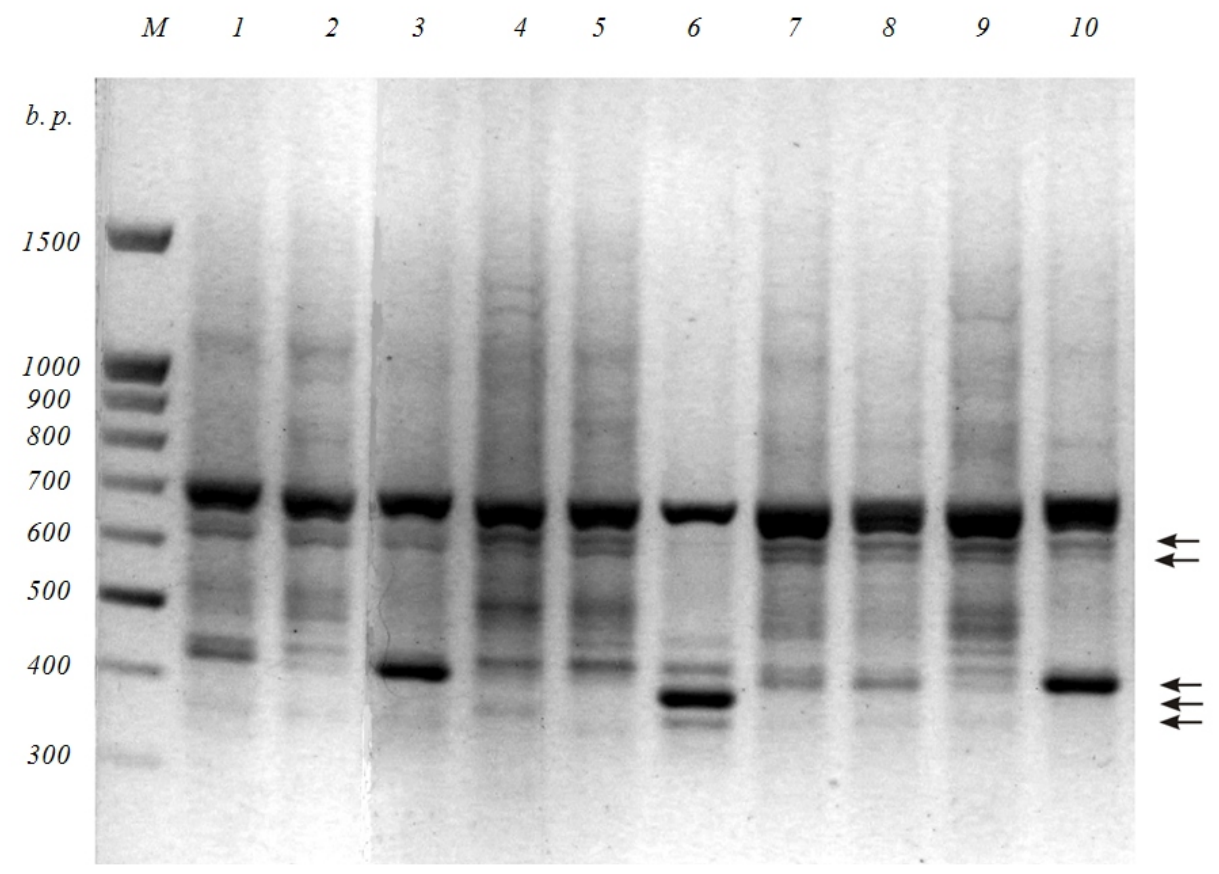

Fig.2 RAPD spectra of DNA of individual plants of somaclonal maize line UKCh-6, obtained using AH-30 primer. Polymorphic fragments are marked by arrows. $M-$ DNA size marker. Numbers of lines correspond to the numbers of UKCh- 6 line plants.

distinguished the somaclones from the initial P346 line, were specific for individual somaclonal lines, whereas others were specific for several lines. Amplicons, equally changed in 3 of 5 somaclonal lines, were formed with Ag-01, M-06, OPA-02 primers (Table 3, amplicons marked by arrows).

Thus, RAPD analysis revealed the differences between the initial P346 line and its somaclonal variants, namely UKCh-5, UKCh-6, UKCh-7, UKCh-8, and UKCh-9 lines. The procedure of somaclonal lines generation included the induction of callus-formation from immature embryos. The resultant callus cultures distinguished by the spontaneous variability were selected by the phenotypic characters - capacity to form totipotent callus and regeneration capacity [6]. Molecular markers used did not show interline polymorphism in initial P346 line, thus allowed excluding possible contribution of this factor to the somaclonal variability at the stage of obtaining callus cultures. Hence, the differences found in somaclonal lines suggest that cultivation of maize tissues in vitro may induce genomic rearrangements at the level of DNA sequences.

Investigated somaclonal lines, unlike initial P346 line, revealed intraline heterogeneity. Analysed plants of each line are direct descendants of one regenerant plant, obtained via self-pollination, and such heterogeneity may be explained by the transition of genome into the heterozygous state and segregation in the course of further sexual reproduction. The transition into the heterozygous state could result from spontaneous variability induced by in vitro culture or in vitro cultivation could result in destabilisation of genome, which was remained in descendants of the regenerant plant. However, available results fail to ascertain the realization of any of the described mechanisms. Meanwhile, the existence of the other group of polymorphic fragments, which did not show intraline variability, but distinguished somaclonal lines from the initial genotype, indicate the possibility of mutations in homozygous form or their selection in further propagation. Similar results were obtained using RAPD-markers on another maize line [11].

We have established some details of genomic changes, which contributed to the formation of somaclonal variants, used for development of the inbred line. Somaclonal lines differ by both the degree of differences from the initial line and in the level of intraline heterogeneity. Besides, there is a correlation between these indices, i.e. UKCh-6 and 
Table 2

RAPD fragments, revealing individual differences of plants of certain somaclonal maize lines

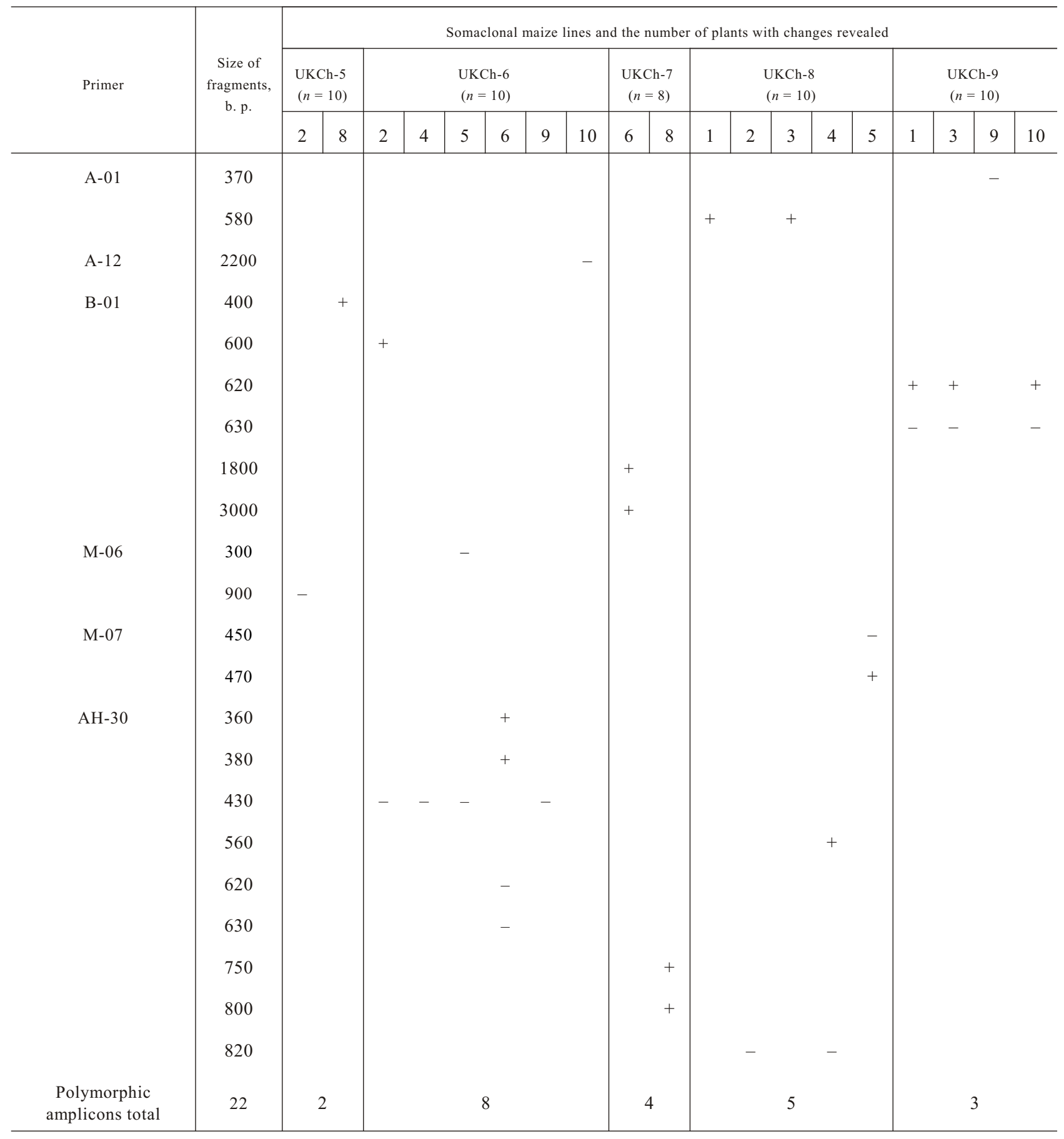

Note: + and - indicate the presence or absence of certain size amplicons (b. p.) compared to the spectrum of initial line P346; $n$ - number of analysed plants. 
Table 3

$R A P D$ fragments, revealing the differences of somaclonal lines from maize output line P346 and remaining stable within some somaclonal lines

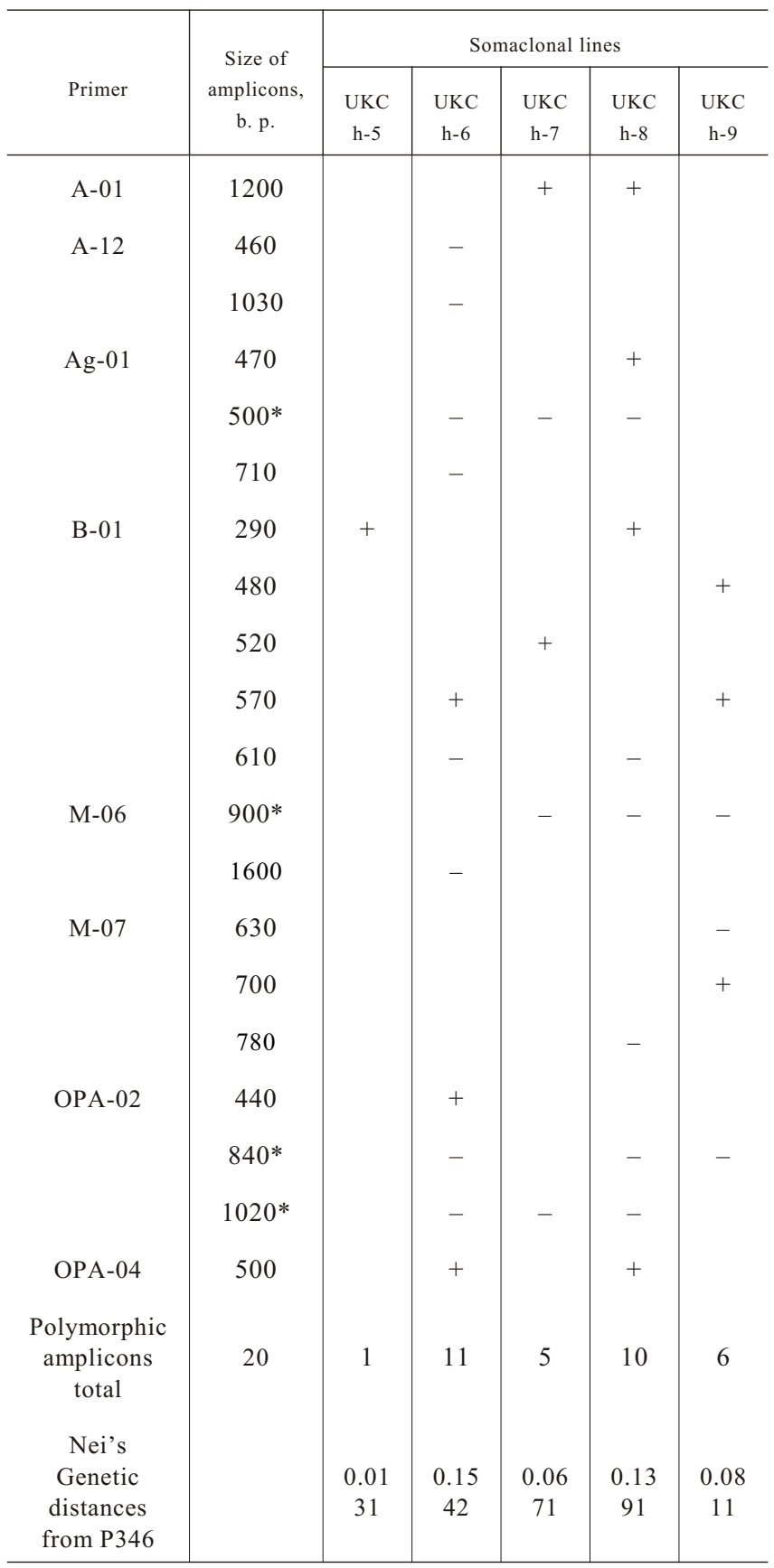

Note: + and - indicate the presence or absence of certain size amplicons (b. p.) compared to the spectrum of initial line P346; * indicate the fragments, polymorphic in 3 of 5 somaclonal lines at the same time.
UKCh-8, showing the highest level of intraline polymorphism, are also characterised by the highest number of polymorphic fragments, which distinguish them from P346 line.

And vice versa, UKCh-5 with the least intraline heterogeneity reveals the least differences from P346. Such positive correlation may be explained by the fact that the changes, induced by in vitro cultivation, lead to the transition of genome to heterozygous state: the more changes occur in genome, the higher number of loci become heterozygous and higher heterogeneity would occur among the seed descendants of the regenerant plant.

One more peculiarity of RAPD-spectra polymorphism of somaclonal lines is displayed in the fact that subset of polymorphic amplicons, which distinguish them from original P346 line, undergoes paralleled changes in several somaclonal lines. The availability of common characters may result from direct selection used upon generation of these lines, however, it can not be excluded that they occur due to existence of mutation in the genome "hot-spots", which undergo changes in condition of stress upon culture initiation and further in vitro cultivation [13].

Molecular and genetic changes in genome, induced by cultivation of tissues in vitro, were also revealed in other representatives of flora. In particular, high level of genetic polymorphism with RAPD-markers was revealed in callus clones of tomatoes, which differed in their ability to grow on hormone-free medium [14]. Variability of RAPDand ISSR-amplicons has been revealed through genomic analysis of Codonopsis lanceolata, obtained by micropropagation [15]. At the same time, insignificant polymorphism has been revealed for the ginseng lines [16], and in almond and Chlorophytum arundinaceum, obtained by microclonal multiplication in vitro, RAPD and ISSR spectra variability was not determined at all $[17,18]$. Such significant disagreements in the published data may be explained by different conditions of in vitro cultivation, as well as by the differences in goals, set by the authors. In particular, genome variability, the increase in which was observed at tissue culture in vitro in some cases, may 
be undesirable (for instance, in the case of plant micropropagation) and in other cases useful (due to increase in genetic variability of original material). By the way, the latter was demonstrated during the formation of new somaclonal inbred maize lines. The results of our investigation, along with the study of certain phenotypic selection-genetic features ([6] and some unpublished data) showed once more that the application of tissue culture in vitro together with the corresponding methods of selection allows obtaining the desired genetic changes.

Conclusions. Distinctions between the inbred maize line P346 and its derivative somaclonal lines, obtained using in vitro culture, have been established.

Somaclonal lines were determined to differ between themselves from the initial line by the degree of distinctions and by the level of intraline heterogeneity. Positive correlation between these indices has been revealed.

A subset of polymorphic amplicons, which distinguish somaclonal lines from P346, was shown to be common for several of them.

The authors are grateful to T. M. Checheneva (Institute of Plant Physiology and Genetics of NAS of Ukraine) and I. A. Gurjeva (V. Ya. Yurjev Institute of Plant Production of UAAS) for the presented seed material. The work was partially supported by Department of Science and Technology Programmes of Ministry of Science and Education of Ukraine as part of project No.03.02.03/0014128.

Генетический полиморфизм сомаклональных линий кукурузы, полученных от линии Р346

Д. Н. Майданюк, И. О. Андреев, Е. В. Спиридонова, В. А. Кунах

Резюме

Методом RAPD-анализа установлены отличия между инбредной линией P346 и пятью сомаклональными линиями кукурузы Zea mays, полученными из нее через культуру тканей in vitro: УКЧ-5, УКЧ-6, УКЧ-7, УКЧ-8 и УКЧ-9. Показано, что сомаклональные линии различаются между собой по величине генетических расстояний от исходной линии Р346, а также по уровню внутрилинейной гетерогенности. Между этими показателями наблюдается положительная взаимосвязь. Часть полиморфных ампликонов, отличающих сомаклональные линии от исходной линии, оказались общими для нескольких из них.
Полученные данные наряду с результатами проведенного ранее изучения отдельных фенотипических селекиионно-генетических признаков ещче раз продемонстрировали, что применение культуры тканей in vitro в сочетании $c$ соответствующими методами отбора позволяет получать желаемые генетические изменения.

Ключевые слова: кукуруза, культура тканей in vitro, coмаклональные линии, RAPD-анализ, геномные перестройки.

\section{REFERENCESE}

1. Dowswell C. R. Maize in the world economy.-New York: Westview press Inc., 1996.-288 p.

2. Козубенко Л. В., Гурьева И. А. Селекция кукурузы на раннеспелость.-Харьков: Урожай, 2000.-240 с.

3. Jain $S$. $M$. Tissue culture-derived variation in crop improvement // Euphytica.-2004.-118.-P. 153-166.

4. Кунах В. А. Біотехнологія лікарських рослин. Генетичні і фізіолого-біохімічні основи.-К.: Логос, 2005.-730 c.

5. Чеченєва Т. М., Гур'єва І. А. Порівняльне дослідження сомаклональних інбредних ліній кукурудзи за кількісними ознаками // Генетика в Україні на межі тисячоліть.-К.: Логос, 2001.-Т. 1-С. 586-589.

6. Чеченева T. Н. Спонтанная и индуцированная изменчивость кукурузы in vitro: Дис. д-ра биол. наук: 03.00.15/ Институт физиологии растений и генетики НАН Украины.-К., 2003.-302 с.

7. Murashige T., Skoog F. A revised medium for rapid growth and bioassays with tobacco tissue cultures // Physiol. Plant.-1962.-15.-P. 473-497.

8. Rogers S. O., Bendich A. J. Extraction of DNA from milligram amounts of field plant tissues // Plant Mol. Biol.-1985.-5.-P. 69-76.

9. Nei M. Genetic distance between populations // Amer. Naturalist-1972.-106.-P. 283-292.

10. Yeh F. C., Rongcai Y., Boyle T. 1999. POPGENE. Version 1.31. University of Alberta, Edmonton, Canada.

11. Осипова Е. С., Ковеза О. В., Троиџкий А. В., Долгих Ю. И., Шамина 3. Б., Гостимский С. А. Выявление специфических фрагментов у сомаклонов кукурузы и создание на их основе SCAR-маркеров // Генетика.-2003.-39, № 12.C. $1664-1672$.

12. Майданюк Д. Н., Андреев И. О., Спиридонова Е. В., Чеченева T. Н., Кунах В. А. Геномная изменчивость линии кукурузы Black Mexican Sweet Corn C456 в культуре in vitro: результаты RAPD-анализа // Вісн. Укр. тов-ва генетиків і селекціонерів.-2006.-4, № 1.-С. 58-67.

13. Linacero R., Freitas A. E., Vбzquez A. M. Hot spots of DNA instability revealed through the study of somaclonal variation in rye // Theor. and Appl. Genet.-2000.-100.-P. 506-511.

14. Bogani P., Simoni A., Lio P., Scialpi A., Buiatti M. Genome flux in tomato cell clones cultured in vitro in different physiological equilibria. II. A RAPD analysis of variability // Genome.-1996.-9.-P. 846-853.

15. Guo W. L., Gong L., Ding Z. F., Li Y. D., Li F. X., Zhao S. P., Liu B. Genomic instability in phenotypically normal regenerants of medicinal plant Codonopsis lanceolata Benth. et Hook. f., as revealed by ISSR and RAPD markers // Plant Cell Rep.-2006.-25.-P. 896-906.

16. Козыренко М. М., Артюкова Е. В., Лауве Л. С., Журавлев Ю. Н., Реунова Г. Д. Генетическая изменчивость кал- 
лусных линий женьшеня (Panax ginseng) // Биотехнология.-2001.-№ 1.-C. 19-26.

17. Martins M., Sarmento D., Oleveira M. M. Genetic stability of micropropagated almond plantlets, as assessed by RAPD and ISSR markers // Plant. Cell Rep.-2004.-23.-P. 492-496.

18. Lattoo S. K., Bamotra S., Saprudhar R., Khan S., Dhar A. K. Rapid plant regeneration and analysis of genetic fidelity of $i n$ vitro derived plants of Chlorophytum arundinaceum Baker - an endangered medicinal herb // Plant Cell Rep.-2006.-25.-P. 499-506.

УДК 575.22:633.15+581.143.6

Надійшла до редакції 22.01.07 